\title{
Mística, teologia e poesia na voz de mulheres: 0 protagonismo feminino na mística medieval ${ }^{*}$
}

\author{
Mystics, Theology and Poetry through the voice of women: \\ the female protagonism in medieval mysticism
}

CeCI Maria Costa Baptista Mariani (iDa

\section{Resumo}

O artigo tematiza o problema da possibilidade de se caracterizar uma mística no feminino. Trata do protagonismo da mulher na mística medieval, usando como referência pesquisas de doutorado realizadas nos Programas de Pós-graduação em Ciências da Religião no Brasil. Elege os trabalhos dedicados às obras de beguinas, consideradas maiores, a saber, Hadewijch de Antuérpia, Mechthild de Magdeburg e Marguerite Porete. Por meio de metodologia bibliográfica procura demonstrar que é possível caracterizar uma mística no feminino, especialmente considerando a maneira com que essas mulheres lidam com a centralidade do desejo na experiência de Deus.

Palavras-chave: Mística. Mulher. Beguinas. Teologia. Desejo de Deus.

\footnotetext{
* Parte desse artigo é fruto de discussões prévias publicadas em: MARIANI, C. M. C. B. Marguerite Porete, teóloga do século XIII: experiência mística e teologia dogmática em "O espelho das almas simples" de Marguerite Porete. 2008. 211f. Orientador: Luiz Felipe Pondé. Dissertação (Doutorado em Ciências da Religião) - Pontifícia Universidade Católica de São Paulo, São Paulo, 2008.

a Pontifícia Universidade Católica de Campinas (PUC-Campinas), Campinas, SP, Brasil. Doutora em Ciências da Religião, e-mail: cecibm@puc-campinas.edu.br
} 


\section{Abstract}

This article addresses the problem of the possibility of defining the mysticism of the feminine. It approaches women's protagonism in medieval mystics, using doctorate research from the Brazilian Graduate Programs in Religion Science as reference. It elects projects dedicated to the work of the beguines Hadewijch of Antuérpia, Mechthild of Magdeburg e Marguerite Porete. Through bibliographic methodology it seeks to demonstrate that it is possible to distinguish a mysticism of the feminine, especially considering the manner in which the referred women deal with the desire's centrality in the experience of God

Keywords: Mystics. Women. Beguines. Theology. God's Will.

\section{Introdução: "Toda mulher é mulher da vida!"}

Para introduzir este artigo que pretende tratar de mística, teologia e poesia na voz de mulheres, no contexto da reflexão sobre hermenêuticas do feminino, gostaríamos inicialmente de fazer referência a uma artista brasileira, a cantora e compositora Rita Lee. Hoje uma senhora septuagenária, Rita Lee é autora de um vasto repertório. Em várias músicas propõe interpretações do feminino. Quero destacar a música “Pagu”, composta em parceria com Zélia Duncan e lançada no disco 3001 no ano 2000, pedindo, desde então, licença poética para trazer ao contexto da reflexão em Ciências da Religião e Teologia versos despudorados. Penso que a ousadia se justifica, na medida em que a irreverência das autoras ajuda a levantar elementos relativos à condição feminina.

Pagu foi Patrícia Galvão (1910-1962), uma jornalista e ativista política brasileira, conhecida por sua luta contra a ditadura de Getúlio Vargas. Foi a primeira mulher no Brasil a ser presa por motivos políticos. Na música que a homenageia, Rita Lee fala do feminino e seus desafios. Começando pela inquisição, a música lembra da perseguição às mulheres sob a acusação de feitiçaria:

Mexo, remexo na inquisição

Só quem já morreu na fogueira sabe o que é ser carvão

Eu sou pau pra toda obra, Deus dá asas à minha cobra

Minha força não é bruta, não sou freira nem sou puta (LEE; DUNCAN, 2000). 
Ao falar de mulher que mexe com fogo e vai para a fogueira, a música faz lembrar tantas mulheres condenadas por feitiçaria. Criado no século XIII, o Tribunal da Inquisição se ocupa da repressão às heresias e também de casos de feitiçaria. Em 1486, informa Jean-Claude Schmitt (2002), os dominicanos Jacobus Sprenger e Henrique Institor publicam o Malleus maleficarum (O martelo das feiticeiras), uma espécie de suma escolástica sobre a feitiçaria. A obra, claramente misógina, como indica o título, compila saber demonológico, descreve práticas e malefícios das feiticeiras contemporâneas e enumera medidas de repressão ao mal. Assume-se que, mesmo existindo feiticeiros, as culpadas pelo mal seriam as mulheres.

Tratando-se da inquisição, não se pode deixar de fazer memória também às mulheres - as beguinas, por exemplo - que, ao se aventurarem na busca de caminhos alternativos ao casamento e ao convento - destinos reservados ao feminino - , ousaram outro estilo de vida e acabaram condenadas.

Dando um salto da Idade Média à contemporaneidade, a música “Pagu”, além da referência à condenação de tantas mulheres associadas à feitiçaria, denuncia a ditadura da beleza imposta à mulher: "Porque nem toda feiticeira é corcunda, nem toda brasileira é bunda/Meu peito não é de silicone, sou mais macho que muito homem (Ibidem).

A historiadora Mary del Priori, refletindo sobre a condição feminina a partir da mulher brasileira, afirma que, apesar das inúmeras mudanças ocorridas no século XX e da consolidação de muitas revoluções no início do século XXI (entre elas, a revolução na área da comunicação e da biotecnologia), a mulher ainda atende a prescrições. Não mais do marido, do padre ou do médico, mas da mídia, que a obriga a um padrão que associa juventude, beleza e saúde. No decorrer do século XX, ela argumenta, o corpo feminino foi despido e incentivado a se expor em público, o que exigiu o uso de cremes, vitaminas, silicones etc.

A associação entre juventude, beleza e saúde, modelo das sociedades ocidentais, aliada a práticas de aperfeiçoamento do corpo, intensificou-se brutalmente, consolidando um mercado florescente que comporta indústrias, linhas de produtos, jogadas de marketing e espaços de mídia (DEL PRIORI, 2014, p. 178). 
Para completar, ainda da música "Pagu", citamos uma estrofe que contém uma frase que desnorteia as interpretações lineares do feminino e brinca com a imagem de "rainha do lar", não estabelecendo oposição entre a dona de casa com seus afazeres domésticos e a mulher com grande engajamento político, como é o caso de Pagu:

Sou rainha do meu tanque, sou Pagu indignada no palanque Fama de porra-louca, tudo bem, minha mãe é Maria ninguém Não sou atriz, modelo, dançarina

Meu buraco é mais em cima (LEE; DUNCAN, 2000).

As autoras, podemos correlacionar, contrapõem-se nessa estrofe, ao que Betty Friedan vai chamar de "mística feminina", referindo-se a um “espírito" que circunscreve a condição feminina ao casamento e à maternidade, a uma imagem à qual a mulher procura se amoldar. Mística que, segundo Friedan, afirma que o valor mais alto e o compromisso único da mulher é a realização de sua feminilidade, e que provém da afirmação de que a mulher "só pode encontrar realização na passividade sexual, no domínio do macho, na criação dos filhos, e no amor materno":

\begin{abstract}
A mística feminina afirma que o valor mais alto e o compromisso único da mulher é a realização de sua feminilidade. Afirma ainda que o grande erro da cultura ocidental, no decorrer dos séculos, foi a desvalorização dessa feminilidade. Diz ainda que esta é tão misteriosa e intuitiva e próxima à criação e à origem da vida, que a ciência humana talvez jamais a compreenda. Contudo, por mais essencial e diferente que seja, de modo algum é inferior à natureza do homem; em certos aspectos pode até ser superior. O erro, diz a mística, a raiz do problema feminino no passado, é que as mulheres invejavam os homens, tentavam ser como eles, em lugar de aceitar sua própria natureza, que só pode encontrar realização na passividade sexual, no domínio do macho, na criação dos filhos, e no amor materno (FRIEDAN, 1971, p. 40).
\end{abstract}

Entendemos, em acordo com Fernanda Henriques, que o foco em testemunhos femininos tem grande importância para a pesquisa atual. Ela afirma que a contemporaneidade pós-moderna, símbolo de deslocação e nãocentralidade, fez emergir perspectivas teóricas novas - entre elas, 0 feminismo - críticas de uma racionalidade que tomou o neutro, o objetivo, o abstrato e o universal como norma do saber e do ser. Racionalidade que reduziu o particular, o contextual, o diferente a perspectivas marginais. 
Estilhaçar o centro e valorizar a relatividade para possibilitar o diálogo entre as diferenças é, para ela, uma tarefa em prol de um renascimento do pensar. Vale citar as suas próprias palavras:

$\mathrm{Na}$ verdade, o estilhaçar do centro tem como correlato uma dupla situação positiva: por um lado, faz tomar consciência de que cada um de nós ocupa apenas uma posição entre muitas outras, e, por outro, dá legitimidade às vozes plurais, locais, em suma, à diversidade como valor. Por essa via, ele pode constituir-se como anúncio da necessidade de diálogo entre as diferenças e originar, como consequência, rearrumações dos olhares teóricos que tornem visíveis os velhos e discriminadores paradigmas do pensar (HENRIQUES, 2016, p. 136-137).

A valorização das diferenças, que desbanca a razão totalitária, ela ressalta, deve potencializar a configuração de uma racionalidade aberta e integradora, um pensar que escute e respeite a realidade na sua profundidade abissal e na sua diversidade complexa. Fernanda Henriques propõe tirar partido da razão em crise, ou razão débil, e fazer uma exploração fina do sentido dessa crise, que indica que o conhecimento é condicionado pela inserção humana na história, sociedade e cultura, e por sua corporeidade. Para que se abram novas formas de conhecimento e compreensão da realidade, ela afirma, faz-se necessário, em relação aos parâmetros epistemológicos:

- Demarcar-se do padrão epistemológico ocidental que instaurou as ideias de neutralidade, universalidade e objetividade como bandeiras da verdade e do valor do saber, assentes na ideia de uma razão pura, transparente e asséptica que produzisse e fornecesse um conhecimento sem impressão digital.

- Não abandonar a intencionalidade universal, mas saber demarcar-se da universalidade abstrata do lluminismo, procurando uma universalidade assintóptica, que marca uma direção, um horizonte regulador.

- Finalmente, fazer entrar no campo do saber o valor da argumentação, contribuindo para a criação de uma "cultura de razões" e para a defesa da necessidade de se procurarem diferentes lugares de explicação e de compreensão da realidade (HENRIQUES, 2016, p. 138-139).

Compartilhamos da compreensão de Fernanda Henriques de que uma melhor percepção da realidade pede a escuta de vozes que foram colocadas na periferia da racionalidade moderna dominante, uma hermenêutica desses 
discursos tendo como pressupostos a historicidade, a fragmentação, a finitude e, principalmente, a interação entre o metafórico e o conceitual, o que pressupõe um conceito ampliado de racionalidade, abrindo espaço para a poesia como compreensão da realidade e reveladora de sua dimensão transcendental e mística.

Para finalizar este ponto, podemos lembrar a música de autoria de Milton Nascimento e Fernando Brant em homenagem à atriz Fernanda Montenegro (gravada por Simone no álbum Delírios, delícias), que também diz muito sobre a condição feminina:

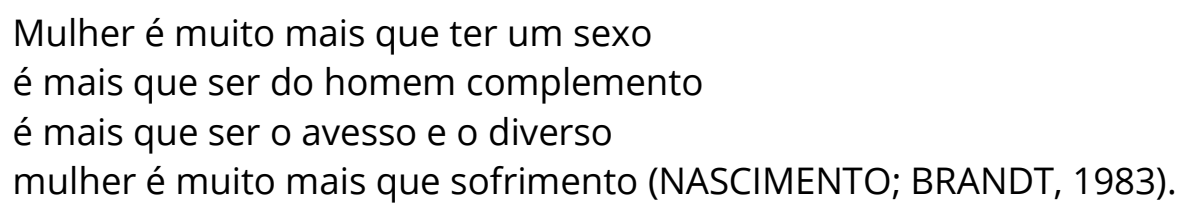

Ao longo das estrofes, os autores desmancham as várias tentativas de definição de mulher:

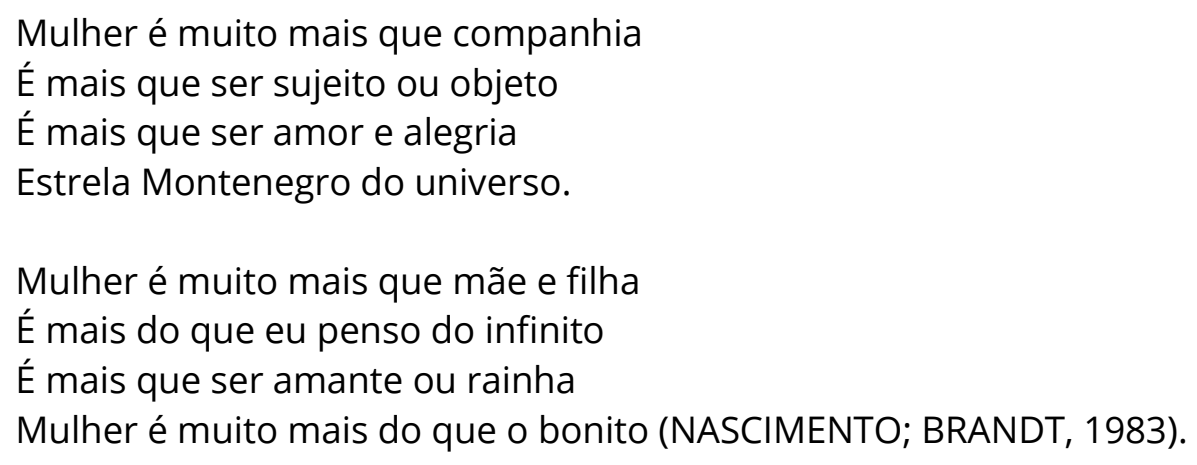

Ao fim, uma estrofe genial, na qual vemos convertida a designação "mulher da vida", dirigida às mulheres prostituídas, em enaltecimento do feminino da vida:

Mulher é a vida

a vida é mulher

toda mulher é mulher da vida (NASCIMENTO; BRANDT, 1983).

Este artigo pretende, através de uma metodologia bibliográfica exploratória, trazer contribuições para a caracterização da mística no feminino a partir das obras de beguinas consideradas maiores, a saber, Hadewijch de 
Antuérpia, Mechthild de Magdeburg e Marguerite Porete. Elegemos, neste artigo, principalmente as pesquisas realizadas nos Programas de Pósgraduação em Ciências da Religião no Brasil.

\section{Mística no feminino: um questionamento que persiste}

A Mística costuma ser definida como conhecimento experimental de Deus, a dimensão profunda que existe em toda a experiência de fé, experiência inefável de unidade participante do Amor infinito que é Deus em seu Mistério. Fruto dessa experiência é um coração sedento. Místicos e místicas experimentam um desejo profundo despertado por Deus, uma paixão infinita, um amor sem limite, que os leva a buscar empreender um caminho de libertação das paixões humanas e estabelecer vínculos novos com o mundo orientados pelo amor a Deus.

De acordo com o reconhecido estudioso Marco Vanini, em entrevista publicada na Revista do Instituto Humanitas Unisinos, na qual se tematizou a contribuição das mulheres para a Mística, não se pode falar de mística feminina num sentido essencial. Para ele, "falar de mística feminina é [... ] um fruto do nosso tempo, no qual a emancipação feminina, o feminismo, a historiografia de 'gênero', de um campo no qual é legítima, transbordou para fora dos limites" (VANINI, 2012, p. 7). Não havendo, segundo o autor, uma abordagem mística feminina diferente da masculina, ele ressalta, entretanto, a contribuição significativa das mulheres para a história da espiritualidade e da Mística nos séculos passados, quando as mulheres não tinham acesso à instrução (VANINI, 2012, p. 7). É fato que as mulheres têm participação ativa no universo religioso, e que são consideradas "mais religiosas" que os homens. No entanto, não se pode negar que, historicamente, os homens têm tido domínio sobre o sagrado em diferentes sociedades.

É notável a ausência das mulheres nos espaços que definem as crenças, as políticas pastorais e a organização das instituições religiosas, afirma Maricel Mena López em editorial da revista Horizonte sobre relações de gênero e religião, publicado em 2015. O campo da prática é o espaço da mulher definido e justificado teologicamente. As religiões, afirma essa autora, têm uma visão 
antropológica que delimita os papéis masculinos e femininos com referência ao sagrado e, por isso, torna-os intocáveis (MENA LÓPEZ, 2015, p. 1199-1200). O que se observa na história da mística e espiritualidade é que, apesar da associação que se fez entre a mulher e o pecado e a corrupção, como lembra Carolina Teles Lemos em artigo que tematiza a mística feminina, algumas desenvolveram estratégias de resistência e ousaram falar, a partir de um ponto de vista feminino, de sua própria experiência, do lugar da "fraqueza feminina" (LEMOS, 2012). A análise de Silvia Schwartz esclarece esse ponto e acrescentaIhe a problemática da corporeidade, que teve grande significado especialmente na Alta Idade Média, mas que continua tendo ecos na atualidade. Com referência à contribuição feminina para a mística na Alta Idade Média, ela afirma:

A associação da mulher com o aspecto corporal da natureza humana, sujeito ao pecado e à corrupção que denegria e inscrevia a mulher sob a hierarquia masculina, passa a ser também um meio através do qual as mulheres alcançavam a santificação e eram autorizadas a escrever, ou, na maior parte das vezes, a ditar suas visões e revelações aos religiosos a elas ligados.

Apesar das normas da espiritualidade feminina determinadas pelo poder eclesiástico masculino, algumas mulheres místicas, Marguerite Porete entre elas, desenvolveram certas estratégias de resistência, de dissonância e ousaram falar a partir de um ponto de vista feminino, definido em relação a si mesmo, sem autorização.

A maioria das mulheres medievais, incluindo Mechthild de Magdeburgo e Hildegard de Bingen, utilizavam o topos da fraqueza feminina: Deus escolhe as coisas fracas - as mulheres - para confundir os fortes - os homens (SCHWARTZ, 2012, p. 66).

De fato, podemos dizer que será no âmbito da mística que a mulher encontrará espaço de expressão no campo da teologia. Com base na obra da Petroff, Leda Seixas, em tese de doutorado sobre as visões de Hadewijch de Antuérpia, afirma que, na Europa medieval, as mulheres excederam os homens em número de textos místicos produzidos. Consequência, em parte, ela explicita, de transformações contextuais que mudaram a condição feminina. Entre essas transformações podemos destacar a importância atribuída ao culto à Maria; o surgimento da literatura cortês que louva a paixão avassaladora do cavaleiro dedicado ao serviço amoroso de uma dama 
inacessível e eleva o status da mulher a senhora na relação com o poeta que se coloca como seu vassalo; o contexto de guerra e cruzadas que, provocando a morte de muitos homens, obriga as mulheres a assumirem responsabilidades tradicionalmente masculinas (SEIXAS, 2020).

Segundo McGinn, na nova mística que floresce no século XIII, destacase a presença feminina. Novas formas de cooperação entre homens e mulheres na busca de uma vida apostólica e de um conhecimento amoroso de Deus e o aparecimento de novas formas de linguagem, associadas ao uso da língua vernácula, possibilitaram o surgimento da minne-mystik. Essa "mística cortesã" vai combinar a mística dos comentários monásticos ao Cântico dos Cânticos com os temas do fin'amour cortesão, possibilitando um novo aprofundamento (MCGINN, 2017). Entre as beguinas encontram-se autoras exemplares desses escritos místicos, que têm como traço característico o caráter ao mesmo tempo especulativo e experimental. O movimento Beguinal representou, na Idade Média, uma alternativa de vida religiosa leiga. Nas beguinagens, surgidas no século XII, mulheres viviam do próprio trabalho: tecelagem, bordado, costura, ensinamento de crianças e serviços a damas idosas. Algumas desenvolveram intensa vida espiritual e, a partir dessas experiências, produziram literatura de grande valor espiritual.

\section{O protagonismo da mulher na mística medieval}

Em relação aos esforços para delinear os contornos de uma mística no feminino, podemos citar alguns trabalhos que têm feito emergir vozes importantes de mulheres que permaneceram por séculos encobertas, obras reconhecidamente místicas, narrativas instigantes e críticas.

Podem-se conferir, por exemplo, estudos como o de Victoria Cirlot e Blanca Gari, interessados em recuperar a memória de mulheres e suas contribuições para a história do pensamento. São pesquisadoras de inspiração feminista, no entanto, de um feminismo que ultrapassa a tentação de uma interpretação rasa que opõe, de maneira absoluta, feminino e masculino. É um feminismo crítico, mas também profundamente respeitoso da importância da Tradição. O livro La mirada interior, escritoras místicas y visionarias en la Edade Media (CIRLOT; GARÍ, 1999), das autoras acima citadas, é um trabalho que 
retoma escritos de mulheres medievais na busca de compreender o fenômeno da escritura mística feminina na Idade Média. As autoras articulam texto e contexto de forma a evitar uma apropriação contemporânea dessas escrituras, a qual conferindo nomes modernos para as experiências próprias de outros tempos, repete sempre o movimento de conquista.

Podem-se citar, também, os estudos de Luisa Muraro, Lingua materna scienza divina: scritti sulla filosofia mistica da Margherita Porete (MURARO, 1995); e o mais recente, El Dio delle donne (MURARO, 2003). Luisa Muraro reconhece, no movimento religioso das mulheres no Medievo, cujas pegadas estão em alguns documentos, uma luta que pode ser considerada política, entretanto, que não teria sido questão de poder e justiça, mas sim de um sentido maior e mais livre do estar no mundo.

No Brasil, sobre as três beguinas, Hadewijch de Antuérpia, Machthild de Magdeburg e Marguerite Porete, consideradas maiores - e às quais dedicamos este item - temos como referências importantes de pesquisa a obra Eros e Agape - Minne: amar e desejar Deus na luz fluente da deidade de Mechthild de Magdeburg (AMARAL, 2014); além das teses intituladas Marguerite Porete, teóloga do século XIII: experiência mística e teologia dogmática em "O Espelho das almas simples" de Marguerite Porete (MARIANI, 2008); A béguine e al-Shaykh: um estudo comparativo da aniquilação mística em Marguerite Porete e Ibn'Arabi (SCHWARTZ, 2005) e Amor, sublime Amor: as visões de Hadewijch sob o prisma do referencial psicológico jungiano (SEIXAS, op. cit.), citada anteriormente.

Nos escritos dessas "trovadoras de Deus", segundo Épiney-Burgard e Zun Brum (2007), o simbolismo do amor cortês se funde à expressão metafísica do amor a Deus, graças à convivência com a cultura profana e religiosa que o ambiente urbano em que vivem thes proporciona (ÉPINEYBURGARD; ZUM BRUM, 2007). O ideal proposto por essas místicas é o da Alma nobre identificada com o cavaleiro que aceita todas as provas impostas por sua dama, como na novela cortesã. Deus é a Dama Amor, "amor de longe", como o denomina Marguerite Porete, almejado por desejo profundo e às vezes violento, objeto de amor impossível de se possuir. Para algumas mulheres do século XIII, afirma McGinn: 
o anseio parece tornar-se mais importante do que a posse; quer dizer, em alguns casos, a fruição do amor vem residir na paradoxal não fruição do contínuo anseio pelo Amado. [...] em certo número de mulheres místicas [...] há uma fusão paradoxal de estados na qual a ausência é presença e vice-versa (MCGINN, op. cit., p. 259).

A obra de Hadewijch da Antuérpia (1200-1260) é composta de cartas, visões e poemas. Em seus escritos, traduz com maestria a intensidade e emoção do drama que experimenta em sua relação consigo mesma e com Deus. Usa imagens da vida cavalheiresca para falar do desejo de Deus. Em estilo trovadoresco, canta o amor ao Amor, apresentando o último como uma dama - Minne - cuja força e riqueza deve ser louvada. Em seus versos, Minne é Deus, o Amor inacessível a quem a alma submete sua devoção. O amor ao Amor significa, para ela, o desejo de um Amor que escapa à influência do amante (ÉPINEY-BURGARD; ZUM BRUM, op. cit).

Ó poderosa, maravilhosa minne,

Tu que tudo podes vencer com maravilha!

Vence-me de modo que eu possa vencer-te

Em tua invicta força (HADEWIHCH, 1980, p. 178 apud SEIXAS, op. cit, p. 127).

A busca amorosa da alma, para ela, mesmo direcionada a um amor inacessível, almeja a união com Deus. Preparada pelo despojamento e consciente da própria insuficiência, a alma chega, elevada por Cristo, a participar da vida intratrinitária. Hadewijch chega a afirmar que a alma é, pela graça, o que Deus é por natureza - divina e capaz de uma verdadeira troca de amor com Ele:

A razão sabe que Deus deve ser temido, que ele é grande e que o homem é pequeno. Mas se ela tem medo da grandeza divina ao lado de sua pequenez, se ela não ousa afrontar e duvidar de ser a criança preferida, não pode conceber que o Ser imenso lhe convém, - isso resulta que muitas das almas não tentam uma vida tão grande. [...] compreenda então a natureza profunda de vossa alma, e o que isto quer dizer: "alma". A alma é um ser que atinge o olhar de Deus, e por quem Deus em troca é visível... A alma é um abismo sem fundo em quem Deus se satisfaz, enquanto que reciprocamente ela se satisfaz nele. A alma é para Deus um caminho livre, onde se lançar até suas últimas profundezas; e Deus é para a alma em troca, o caminho da liberdade, até esse fundo do Ser divino que nada pode tocar senão o fundo da alma. E se Deus não Ihe pertence inteiramente, ele não Ihe satisfaz (DEBLAERE, 1964, p. 1906). 
Hadewijch foi uma visionária. Em suas visões, aponta Seixas, escritas provavelmente para conduzir jovens beguinas a um aprofundamento da vida espiritual, relata sua experiência de amor vivido e retribuído por Deus que traz consigo um conhecimento supremo que é também fonte de resiliência. Por meio de imagens e símbolos que compõe uma narrativa intensa e sensual, como se vê na visão VII, fala de sua união perfeita com Cristo:

Meu coração e minhas veias e todos os meus membros tremeram e convulsionaram com um desejo ardente e, como frequentemente me acontece, tamanha loucura e medo assolaram minha mente, que parecia que se eu não satisfizesse meu Amado, e meu Amado não preenchesse meu desejo, morrendo deveria enlouquecer, e enlouquecendo deveria morrer. Naquele dia minha mente foi invadida tão assustadora e dolorosamente pelo desejo amoroso que cada um de meus membros ameaçou quebrar-se e cada uma das minhas veias estava em contrações. [...]

Desejei que sua Humanidade pudesse se fundir em fruição e ao máximo com minha humanidade, e que a minha pudesse manter-se e ser forte o bastante para atingir a perfeição até que eu pudesse contentá-lo, ele que é a perfeição em si mesma, pela pureza e pela unidade e em todas as coisas para contentá-lo plenamente em todas as virtudes.

[...] ele veio a mim humildemente, como alguém que pertence totalmente a alguém outro. Então ele deu-se a mim na forma de Sacramento, em sua forma externa, como é de costume; e então ele me deu de beber do cálice, na forma e gosto, como é de costume. Depois disso, ele próprio veio a mim, tomou-me inteiramente em seus braços, e pressionou-me contra ele; e todos os meus membros sentiram os dele em total felicidade, de acordo com o desejo do meu coração e da minha humanidade. [...]

Depois disso, permaneci submersa em meu Amado, de modo que me fundi totalmente com ele, e nada mais permaneceu de mim mesma; e eu fui transformada e fui enlevada em espírito, e lá foi-me mostrado a respeito de tais horas [e tive uma revelação de várias horas] (HADEWIJCH apud SEIXAS, op. cit., p. 222-223).

Os escritos de Mechthild de Magdeburg (1270-1282), fundamentados em conhecimento experimental, têm, no centro, o amor que nasce da experiência paradoxal de estar com a alma nua diante da misericórdia divina. Mechthild, aponta Amaral (2014), canta em versos, como "trovadora de Deus", a experiência dolorida e prazerosa do amor de Deus-Trindade que a eleva para que flua. Sua indizível experiência de amor é tal que ela chega à ousadia de dizer que suportaria o inferno para que o seu Amado fosse louvado por toda criatura: 
Meu corpo está em grande tormento, minha alma está em sublime alegria; porque ela contemplou e com seus braços envolveu o seu amado. Ele causa nela pobre desventura, infelicidade (miséria), tormento. Quando ele a eleva, ela flui. Ela não consegue se conter até que ele a traga para dentro dele mesmo. Ela gostaria de falar, mas não consegue porque ela foi totalmente ferida em união sublime com Trindade imponente (o temor da Trindade). Então ele a deixa por um breve momento e ela deve se sentir ansiando. Ela deseja o seu louvor, mas não sabe encontra-lo como ela gostaria. Ela até gostaria que ele a enviasse ao inferno, para que ele fosse louvado além da medida por todas as criaturas. Ela olha para ele e diz para ele: Deus dá-me a sua benção. Ele olha para ela, eleva-a novamente e faz a ela uma saudação que o corpo não consegue expressar (MECHTHILD, apud AMARAL, op. cit., p. 35-36).

No processo amoroso descrito por Mechthild, eros e ágape não competem. São vivenciados como fontes e como "possibilidade humana paradoxal e fragmentada, que se alternam entre si, se confundem, se transformam, e culminam no esvaziamento - estado de certeza e receptividade da graça divina" (AMARAL, op. cit., p. 37). O amor esponsal entre Deus e a alma, constata Amaral, é descrito por essas mulheres como "união de profundidade abissal na qual a alma torna-se completamente equalizada ao Amado e ao Amante Infinito" (AMARAL, op. cit., p. 66). Em seus escritos, elas escrevem sobre suas experiências de união com Deus de maneira sensual e sofrida. A pesquisa realizada por Amaral permite afirmar que, mesmo estando referida a essa tradição monástica tradicional, a linguagem desses escritos ultrapassa a linguagem masculina na ênfase que é dada ao efeito devastador da loucura de amor.

É interessante considerar a ousadia dessas mulheres místicas que se dispuseram a falar de desejo de fruição do divino em uma época em que o sexo era visto como consequência do pecado e o casamento não oferecia condição ao amor por causa dos laços, contratos e obrigações com a família e com a Igreja. Maior ousadia ainda representa a utilização dos recursos simbólicos da cortesia para expressar essa experiência amorosa de paixão sem limites.

A obra da beguina Marguerite Porete (1250-1310), O espelho das almas simples, escrita em língua vernácula, constitui-se num espelho, isto é, um escrito inserido num gênero literário pertencente à tradição cristã que tem como objetivo instruir a respeito de um itinerário espiritual. É um livro que busca descrever o itinerário da alma que, amorosa de Deus, passa por seis 
estados e três mortes até que, aniquilada, tem razão e vontade transformadas pelo encontro com o divino. O espelho de Marguerite, entretanto, é também um romance de amor que tem como protagonista a alma ansiosa, como donzela apaixonada por um rei nobre e cortês que se encontra em uma terra distante, pelo encontro com Deus, o seu Bem-Amado.

\begin{abstract}
Alma (que escreve o livro): - Sobre isso, de maneira semelhante e verdadeira, vos digo: ouvi falar de um rei de grande poder, que era por gentil cortesia, por grande cortesia de nobreza e generosidade, um nobre Alexandre. Mas ele estava tão distante de mim, e eu dele, que não sabia como me consolar. E para que eu me lembrasse dele, ele me deu este livro que representa de alguma maneira o seu amor. Contudo, ainda que eu tenha a sua imagem, não estou menos num país estranho, distanciada do palácio onde vivem os mais nobres amigos desse senhor, que são completamente puros, perfeitos e livres graças aos dons desse rei com que permanecem (PORETE, 2008, p. 32).
\end{abstract}

Na obra, essa beguina, assumindo a via negativa ou apofática, que entende que o encontro com Deus em seu Mistério se situa além de todas as mediações humanas, tem a ousadia de afirmar que seu Bem-Amado, que é Deidade pura sobre a qual a Razão não sabe falar, é aquele que procede do Pai e do Filho, o Santo Espírito. O seu Bem-Amado é o fino amor. Ele a faz viver na alegria e lhe dá sua comida, nutre-a.

Libertada da preocupação com as virtudes e de sua própria vontade, no final do livro, a alma aniquilada, protagonista desse romance que narra seu itinerário espiritual, louva, com uma canção de amor ao estilo trovadoresco, o Amado com quem se encontra unida em seu nada querer:

Por um tempo estive reclusa

Na servidão de uma prisão,

Quando o desejo me aprisionava

Na vontade do afeto.

Lá me encontrou a luz

Do ardente amor divino,

E logo meu desejo eliminou,

Minha vontade e meu afeto,

Que impediam a realização

Do pleno amor divino.

Agora a luz divina

Da prisão me libertou,

E por gentileza me uniu 
À divina vontade de Amor,

Lá onde a Trindade me deu

A delícia de seu amor.

Esse do nenhum homem conhece,

Enquanto à virtude ainda serve,

Ou ao sentimento da natureza, pelo uso da razão (PORETE, 2008, p. 201).

Tendo em si o Amado, a alma tem a força dele no amor. A "perigosa liberdade" é o fruto colhido por essas mulheres que, vivendo em comunidades religiosas, puderam aprender a ler e escrever, tiveram oportunidade de conversar com outras pessoas instruídas e ainda contar com a privacidade para observar os próprios pensamentos. A vida religiosa permitiu às mulheres maior dedicação às atividades intelectuais (SEIXAS, op. cit., p. 94). Tendo essas condições favorecido o florescimento de uma mística na voz de mulheres, há que se acrescentar a essas condições a maneira como a mulher acolhe em seu corpo a experiência que a levará a uma consciência de Deus. A "liberdade perfeita", segundo Marguerite Porete, é a transfiguração sofrida pela alma que se despojou de todas as seguranças exteriores (mandamentos, escrituras, conselhos) e de todas as seguranças interiores (razão e vontade) no seu itinerário de abertura ao acolhimento do amado, que é o Espírito Santo. Tendo sido transformada por Amor em Amor,

\footnotetext{
a alma, perfeitamente livre, é de uma amável nobreza na prosperidade, de uma alta nobreza na adversidade, e de uma excelente nobreza em todos os lugares e por isso - tira aqui a autora, as consequências arriscadas que a levaram a uma problemática relação com a Igreja em sua dimensão institucional - não procura mais a Deus (MARIANI, op. cit., p. 163).
}

Como podemos constatar, as obras dessas mulheres são profundamente críticas. Sabemos que a mística sempre tem uma dimensão crítica, pois implica um itinerário espiritual que, ao alcançar a consciência da presença divina para além de todas a mediações, capta a relatividade de tudo e possibilita uma percepção da realidade inteiramente nova. Essa mística feminina, especificamente, aprofunda a dimensão crítica, porque expressa uma vivência encarnada desse processo. Na narrativa dessas mulheres encontra-se a vivência de um processo de despojamento radical (de nadificação) que as lança a uma experiência de união com o absoluto 
caracterizado por elas como amor infinito, não regido pela necessidade, mas pela abundância e gratuidade. A alma e o corpo, como vemos contemplado em seus escritos, afetados por essa experiência transformadora de amor infinito, já não se submetem ao controle da Instituição (MARIANI; AMARAL, 2015).

É fato que essas mulheres não foram bem compreendidas. O Movimento Beguinal foi, desde muito cedo, alvo da desconfiança eclesiástica. O Concílio de Viena (1311-1312), em decreto que diz respeito principalmente às beguinas, reprova o hábito que usam mesmo sem ser religiosas sob a obediência de uma regra aprovada; acusa-as de que se perdem em “especulações loucas" sobre a Trindade e a essência divina, sobre outros dogmas ou pontos de doutrina e sobre os sacramentos. Na Carta XXIX, informa Seixas (2020), Hadewijch se refere à necessidade de levar uma vida errante e do risco de terminar no cárcere:

Não te perguntes o que me acontecerá, se terei de errar pelo país ou terminarei no cárcere [...]. Vivi todas essas experiências no amor e muito operei pelas pessoas que, tão amiúde, faziam pouco caso de mim. Marguerite Porete também tinha a consciência do risco que corria por não ser compreendida pela 'gente de religião', nem pelas beguinas, suas companheiras de estilo de vida, nem pelos 'padres, clérigos e pregadores' (PORETE, op. cit., p. 201).

Marguerite foi efetivamente considerada culpada pelo Tribunal da Inquisição. Julgada e condenada, morreu queimada na Place de Grève, em Paris, no dia $1^{\circ}$ de junho de 1310.

\section{Considerações finais}

Como vimos, o que se pode observar por meio do estudo dos escritos dessas mulheres é a centralidade do desejo para a experiência mística. Esse elemento não é próprio delas. Gregório de Nissa, bispo, monge, teólogo e santo capadócio do século IV, em suas Homilias sobre o Cântico dos Cânticos, por meio de leitura alegórica, "interpreta o drama amoroso da relação amadoamada, em termos de ausência, desejo, busca, ferida, encontro, como símbolo da verdade de Deus, de sua relação e de sua união" (VELASCO, 2003. p. 24). O encontro com Deus, descrito como união, caracteriza-se, para Gregório, como uma relação em que o desejo é infinito. Quanto mais proximidade da alma, a 
esposa, com Deus, o Amado, mais o desejo cresce e se aprofunda, pois o noivo que se aproxima na noite permanece velado em seu mistério. Por isso, o desejo de Deus é gozo, mas também ferida:

\begin{abstract}
A alma saiu de si mesma e nada te impede de conhecer o que vê. Constantemente, procura o amado, mas ninguém pode dar qualquer resposta. "Procurei-o, mas não encontrei". Como poderemos encontrar o que nenhuma coisa conhecida nos pode apresentar? Não tem forma, limitação, quantidade, lugar, figura. Não podemos imaginar, comparar nem relacionar a nada [...].

Agora a envolve a noite em que o esposo se aproxima sem se deixar ver. Como durante a noite é mais visível o invisível? Faz que a alma sinta sua presença, mas não deixa que o entendimento o compreenda. Velada está aquela natureza que pelo olhar não pode compreender (Homilias sobre o Cântico dos Cânticos GREGÓRIO DE NISSA apud VELASCO, op. cit., p. 32).
\end{abstract}

Sem querer estabelecer estereótipos de gênero para caracterizar a mística feminina esponsal, nupcial e amorosa, por um lado, e a masculina especulativa ou racional, por outro, devemos levar em consideração que a mulher teve e tem uma forma própria de relação com a realidade e, em sua singularidade corpórea, uma maneira própria de lidar com o desejo.

Ao que nos parece, é possível observar nas narrativas femininas uma forma de entrega amorosa específica, considerando que, do ponto de vista simbólico, esclarece a psicanalista Françoise Dolto, o corpo feminino é marcado por uma dinâmica centrípeta, movimento de atração, sedução, desejo de ser penetrada, tornar-se fecunda; diferentemente do corpo masculino, que tem uma dinâmica centrífuga que corresponde ao movimento de penetração em relação ao objeto desejado (DOLTO, 1984).

$O$ desejo não é masculino nem feminino, mas ousamos afirmar que as mulheres, em analogia a suas vivências concretas, podem acrescentar elementos para a compreensão da entrega amorosa necessária ao acolhimento do amor de Deus, os quais, por elas terem tido as vozes silenciadas, não se puderam perceber. Além dessa dimensão receptiva, o corpo da mulher carrega, por exemplo, fluxos hormonais e vivências de fertilidade que são também próprias de sua singularidade corpórea. A maternidade foi e ainda é elemento que possibilita muitas analogias espirituais. Acrescenta-se ainda que, por sua condição histórica milenar de 
submissão ao poder patriarcal, conhece bem a fragilidade humana e a força que, na pobreza, se encontra em Deus.

Nas obras das três beguinas a quem nos referimos, encontramos narrativas sobre o desejo de Deus descritas de forma intensa e corajosa. Na medida em que incluem os impactos corporais da experiência e, de forma até mesmo "despudorada", expõem seus aspectos sensuais, ajudam a reconhecer a integralidade das experiências espirituais. Também não têm medo de confessar a própria fraqueza para anunciar a transformação nelas operada por Deus.

Demostram, com isso, que a espiritualidade é uma experiência encarnada na vida e que implica vivências concretas. Nos escritos, ainda observamos um esforço didático que procura, por meio da partilha de experiências pessoais, expressas em poemas, cartas e visões, orientar formas de trabalhar e ordenar essas vivências sem as negar.

Enfim, outras consequências poderiam ser tiradas na medida em que mais vozes femininas fossem escutadas. Fica aqui uma provocação para as Ciências da Religião e a Teologia, que ainda se encontram longe de uma justiça de gênero, e um convite ao aprofundamento do debate.

\section{Referências}

AMARAL, M. J. C. Eros e Agape - Minne: amar e desejar Deus na luz fluente da deidade de Mechthild de Magdeburg. São Paulo: Reflexão, 2014.

CIRLOT, V.; GARÍ, B. La mirada interior: escritoras místicas y vivionarias en la Edad Media. Barcelona: Martínez Roca, 1999.

DEBLAERE, A. Theóries de la mystique chrétienne. In: Dictionnaire de spiritualité ascétique et mystique, doctrine et histoire. Paris: Beauchesne, 1964.

DEL PRIORI, M. Histórias e conversas de mulher: amor, sexo, casamento e trabalho em mais de 200 anos de história. São Paulo: Planeta, 2014.

DOLTO, F. No jogo do desejo. Rio de Janeiro: Zahar, 1984.

ÉPINEY-BURGARD, G.; ZUM BRUM, E. Mujeres trovadoras de Dios: una tradición silenciada de la Europa medieval. Barcelona: Paidós, 2007.

FRIEDAN, B. Mística feminina. Petrópolis: Vozes, 1971. 
HENRIQUES, F. Filosofia e gênero: outras narrativas sobre a tradição ocidental. Lisboa: Colibri, 2016.

LEE, R.; DUNCAN, Z. Pagu. In: LEE, R. 3001. São Paulo: Universal Music, 2000.

LEMOS, C. T. Mística feminista: interfaces entre místicas religiosas e místicas seculares. Horizonte, Belo Horizonte, v. 10, n. 27, p. 804-830, 3 out. 2012.

MCGINN, B. O florescimento da mística: homens e mulheres da nova mística (12001350). São Paulo: Paulus, 2017. Tomo 3.

MARIANI, C. M. C. B. Marguerite Porete, teóloga do século XIII: experiência mística e teologia dogmática em "O espelho das almas simples" de Marguerite Porete. 2008. 211f. Orientador: Luiz Felipe Pondé Dissertação (Doutorado em Ciências da Religião Pontifícia Universidade Católica de São Paulo, São Paulo, 2008.

MARIANI, C. M. C. B.; AMARAL, M. J. C. A mística como crítica nas narrativas de mulheres medievais. Revista de Cultura Teológica, São Paulo, v. 23, p. 85-107, jul./dez. 2015.

MENA LÓPEZ, M. Género y estudios de la religión. Horizonte, Belo Horizonte, v. 13, n. 39, p. 1199-1205, p. 1199-1200, 30 set. 2015.

MURARO, L. Lingua materna scienza divina: scritti sulla filosofia mistica da Margherita Porete. Nápoles: M. D’Auria, 1995.

MURARO, L. El Dio delle donne. Milano: Mondadori, 2003.

NASCIMENTO, M.; BRANDT, F. Mulher da vida. Intérprete: Simone. Em: SIMONE. Delírios, delícias. Rio de Janeiro: CBS, 1983.

PORETE, M. O espelho das almas simples e aniquiladas e que permanecem somente na vontade e no desejo e no desejo do Amor. Petrópolis: Vozes, 2008.

SCHMITT, J. C. Feitiçaria. In: LE GOFF, J.; SCHMITT, J. C. (Coord.). Dicionário temático do Ocidente Medieval. Bauru: Edusc; São Paulo: Imprensa Oficial do Estado, 2002. p. 423-435.

SCHWARTZ, S. A béguine e al-Shaykh: um estudo comparativo da aniquilação mística em Marguerite Porete e Ibn'Arabi. 2005. Dissertação de doutoramento Universidade Federal de Juiz de Fora, Juiz de Fora, 2005.

SCHWARTZ, S. Marguerite Porete e a "teologia" do feminino divino. Instituto Humanitas Unisinos, v. 385, ano XI, p. 63-y68 19 dez. 2012.

SEIXAS, L. M. P. Amor, sublime Amor: as visões de Hadewijch sob o prisma do referencial psicológico junguiano. 2020. Dissertação (Doutorado em 2020) Pontifícia Universidade Católica de São Paulo, São Paulo, 2020. 
VANINI, M. A experiência do espírito vai além das distinções espaço-temporais e de gênero. Instituto Humanitas Unisinos, v. 385, ano XI, p. 6-11, 19 dez. 2012.

VELASCO, J. M. Doze místicos cristãos: experiência de fé e oração. Petrópolis: Vozes, 2003.

RECEBIDO: $14 / 11 / 2020$

RECEIVED: $11 / 14 / 2020$

APROVADO: 20/03/2021

APPROVED: 03/20/2021 